\title{
Dawstwo narządów w świetle polskiej ustawy transplantacyjnej
}

\author{
Piotr Ochotny \\ Wydział Teologiczny, Uniwersytet Mikołaja Kopernika w Toruniu \\ ul. Gagarina 37, 87-100 Toruń \\ pochotny@poczta.onet.pl • ORCID: 0000-0001-8140-4290
}

\section{Streszczenie}

Bez wątpienia największym problemem medycyny transplantacyjnej jest mała ilość dawców przy równoczesnym, ciągle wzrastającym, zapotrzebowaniu na tkanki i narządy. Celem artykułu jest poszukiwanie odpowiedzi na pytanie: czy i w jakim stopniu polska ustawa transplantacyjna z 1 lipca 2005 r. o pobieraniu, przechowywaniu i przeszczepianiu komórek, tkanek i narządów poszerza krąg potencjalnych dawców organów. W przekonaniu autora polskie regulacje prawne w zakresie transplantologii sprzyjają w optymalny sposób pozyskiwaniu organów. Po pierwsze, pobieranie organów od dawców zmarłych regulowane jest zgodnie z modelem tzw. zgody domniemanej, na podstawie której przyjmuje się, iż dany człowiek za życia wyraził się aprobująco o możliwości ofiarowania swoich organów, a więc faktycznie nie złożył odpowiedniego sprzeciwu, podważającego domniemanie zgody. Po drugie, ustawodawca, posługując się nieostrą klauzulą generalną „szczególnych względów osobistych", dopuszcza możliwość pobrania komórek, tkanek czy narządów w celu przeszczepienia u żywego dawcy niespokrewnionego z biorcą. Po trzecie, ustawa zezwala na pobranie od anonimowych dawców szpiku i innych regenerujących się komórek i tkanek. Po czwarte, w myśl polskiej ustawy transplantacyjnej dopuszczalne jest przeszczepienie ludziom w celach leczniczych komórek, tkanek lub narządów pochodzących od zwierząt. Oczywiście, nie oznacza to, że regulacji transplantacyjnych nie można doskonalić. Należy jednak podkreślić, że zasadniczą przyczyną spadającej liczby transplantacji jest niski poziom świadomości społecznej powodowany brakiem strategii edukacyjnej. Towarzyszy temu atrofia postaw współczujących.

\section{Słowa kluczowe}

transplantologia, dawstwo, zmarły dawca, żywy dawca, dawstwo anonimowe, ksenotransplantacja

\section{Wstęp}

Już od ponad pięćdziesięciu lat, choć w różnym, ale stale rozszerzającym się zakresie, zabiegi transplantacyjne stanowią realną, skuteczną, a często jedyną drogę ratowania lub przedłużania życia pacjentów ze schyłkową niewydolnością wielu narządów, ofiar rozmaitych wypadków oraz osób cierpiących na nowotwory układu krwiotwórczego czy złożone niedobory immunologiczne. Transplantologia, jako dynamicznie rozwijająca się dziedzina medycyny, uległa ogromnemu postępowi, co aktualnie skutkuje zarówno podniesieniem skuteczności tej metody terapeutycznej, jak i znacznym rozszerzeniem wskazań do jej stosowania. Chociaż pierwsze wzmianki o próbach zastąpienia organu uszkodzonego organem zdrowym sięgają starożytnych cywilizacji, to dopiero w XX w. zabiegi transplantacyjne stały się realną możliwością terapeutyczną. $\mathrm{Na}$ świecie żyje obecnie ponad milion ludzi 
z przeszczepionym narządem. Co roku wykonuje się ponad 90 ooo rozmaitych przeszczepów. Tylko w USA w 2016 r. osiągnięto ich rekordowy poziom - 33 ooo. Z podobną sytuacją mamy do czynienia w naszym kraju. Od czasu pierwszego udanego przeszczepienia nerki w 1966 r. medycyna transplantacyjna w Polsce rozwija się bardzo dynamicznie, mimo ograniczeń powodowanych wciąż niedostateczną świadomością społeczeństwa na jej temat. W 28 ośrodkach medycznych co roku wykonuje się ok. 1500 przeszczepień narządów unaczynionych. Ogółem w 2017 r. w Polsce przeszczepiono 1555 narządów (1531 narządów pochodzących ze zwłok i 24 pochodzących od osób żywych) (Web-o1). Łącznie, do chwili obecnej, przeprowadzono ponad 30 ooo operacji transplantacyjnych poszczególnych narządów, takich jak: nerki, serca, wątroby, trzustki, płuca, jak również przeszczepów wielotkankowych: kończyn, twarzy. Dzięki postępowi w dziedzinie immunologii, farmakologii i chirurgii transplantacyjnej, a także stworzeniu systemu opieki medycznej osób przewlekle chorych, w Polsce 5 lat po transplantacji przeżywa $87 \%$ biorców nerki, 73\% biorców wątroby i 61\% biorców serca (Durlik, Cierpka 2015: 13). Świadczy to niewątpliwie o skuteczności tego rodzaju działań medycznych.

Dynamiczny rozwój tej dyscypliny medycznej, a także sukcesy, jakie ma na swoim koncie, otworzył nowe możliwości i perspektywy oraz rozbudził nadzieje wielu pacjentów na wyleczenie i normalne funkcjonowanie, które dotąd nie były możliwe. Wciąż jednak największym problemem medycyny transplantacyjnej jest mała ilość dawców przy równoczesnym, ciągle wzrastającym, zapotrzebowaniu na tkanki i narządy. Transplantacja regulowana jest w prawie polskim w podstawowym zakresie w ustawie z dnia 1 lipca 2005 r. o pobieraniu, przechowywaniu i przeszczepianiu komórek, tkanek i narządów ${ }^{1}$. W świetle tej ustawy

1 Poprzednio (tj. do dn. 1.01.2006 r.) problematykę tę regulowała ustawa $\mathrm{z}$ dnia 26 października transplantacja - co do zasady - jest dopuszczalną przez prawo interwencją medyczną, jednakże na zasadach w niej uregulowanych. Konieczność reglamentacji prawnej tej interwencji wynika z faktu, że tylko z punktu widzenia biorcy przeszczepu ma ona charakter terapeutyczny. Natomiast z perspektywy dawcy przeszczepu (żywego dawcy) interwencja ta przybiera już postać nieterapeutyczną, a czasami wręcz obniża ogólny stan zdrowia i upośledza jego funkcje, okresowo lub na stałe (Żelichowski 2009: 145). Ustawa transplantacyjna, stwarzając spójne i wyraźne ramy prawne transplantacji (podstawę legislacyjną), wprowadza słownik definicji legalnych (ustawowych) zawierających pojęcia ściśle powiązane $\mathrm{z}$ przeszczepami, takie jak: dawca, biorca, dawstwo, komórka, tkanka, narząd, bank tkanek i komórek.

Celem artykułu jest poszukiwanie odpowiedzi na pytanie, czy i w jakim stopniu przyjęte w ustawie regulacje prawne poszerzają krąg potencjalnych dawców organów.

\section{Dawstwo ex mortuo}

Normą jest, iż w ustawodawstwie dotyczącym transplantacji odrębnie reguluje się pobieranie transplantatów do przeszczepów ze zwłok ludzkich (ex mortuo) i od żywych dawców (ex vivo). Czasami ustawodawca wprowadza zasadę subsydiarności, zgodnie z którą pobranie organów od osoby zmarłej ma pierwszeństwo w stosunku do pobierania organów od dawców żywych. Każdorazowo zatem pobieranie organów od żywego dawcy jest możliwe wówczas, gdy brak jest odpowiedniego dawcy zmarłego oraz równie skutecznej, alternatywnej metody leczenia. Wynika to z faktu, że pobranie i przeszczepianie komórek, tkanek i narządów od żywego dawcy zawsze wiąże się ze stosunkowo dużym ryzykiem dla jego zdrowia. Rozwiązanie to budzi liczne kontrowersje medyczne i prawne. W przypadku transplantacji wiadomo, że niektóre narządy (np. nerki) pobierane od żywych dawców funkcjonują dłużej

1995 r. o pobieraniu i przeszczepianiu komórek, tkanek i narządów (Dz.U. Nr 138, poz. 682 z późn. zm.). 
niż przeszczepione od dawców zmarłych. Po wtóre, ustawodawcy wprowadzającemu zasadę subsydiarności zarzuca się realizację idei paternalizmu w stosunku do jednostek (Ochmański 2011: 87).

Ustawodawca polski nie wprowadził do ustawy wyraźnie sformułowanej zasady subsydiarności. Oznacza to, że obydwa źródła organów traktowane są w sposób równorzędny. Z kolejności norm wynika, że ustawodawca jako pierwsze normuje pobieranie organów ze zwłok ludzkich. Nie należy jednak przywiązywać do tego znaczenia normatywnego, a tym bardziej wyprowadzać stąd zasady subsydiarności. Pobieranie organów od dawców zmarłych regulowane jest na ogół w ustawodawstwie światowym zgodnie $\mathrm{z}$ jednym z trzech modeli:

- $\quad$ model sprzeciwu - zgodnie z którym pobranie organów od osoby zmarłej jest dozwolone, o ile denat nie wyraził za życia sprzeciwu w odpowiedniej formie (np. Hiszpania, Belgia, Austria, Finlandia, Francja, Portugalia, Rosja);

- model zgody - zgodnie z którym zmarły może być dawcą, o ile za życia wyraził zgodę (wąskie ujęcie), lub tego nie uczynił, a zgodę wyrażają osoby bliskie (np. Wielka Brytania, Niemcy);

- model informacji - zgodnie z którym pobranie jest możliwe, o ile zmarły wyraził zgodę za życia, w przypadku zaś gdy tego nie uczynił, równoznaczny ze zgodą jest brak sprzeciwu poinformowanych w odpowiednim czasie bliskich zmarłego, np. Szwecja, Norwegia (Ochmański 2011: 87-88).

W polskiej ustawie transplantacyjnej występuje model sprzeciwu, zgodnie bowiem $\mathrm{z}$ art. 5 ust. 1 „pobrania komórek, tkanek lub narządów ze zwłok ludzkich w celu ich przeszczepienia można dokonać, jeżeli osoba zmarła nie wyraziła za życia sprzeciwu" ${ }^{2}$. Oznacza

2 Zasadę zgody domniemanej przyjmuje także Kodeks Etyki Lekarskiej, który stwierdza: „Lekarz może pobrać narządy i tkanki ze zwłok w celu ich przeszczepienia, o ile zmarły nie wyraził za życia sprzeciwu" (Kodeks Etyki 2004: art. 33). Kodeks w pierwotnej wersji został uchwalony 14 grudnia to, że przypuszczalnie za życia wyraziłaby się aprobująco o możliwości ofiarowania swoich organów potrzebującej osobie. Decyzja negatywna, zakazująca pobrania przeszczepów, powinna wynikać ze stwierdzenia podważenia domniemania zgody donatora (Tokarczyk 2000: 24). Podważenie to powinno się opierać na istnieniu jednej $\mathrm{z}$ form sprzeciwu na pobranie narządów wyrażonego przed śmiercią przez potencjalnego dawcę przeszczepów: wpis do Centralnego Rejestru Sprzeciwów; pisemne oświadczenie podpisane własnoręcznie; ustne oświadczenie, które zostało złożone w obecności przynajmniej dwóch świadków i pisemnie przez nich potwierdzone (ustawa 2005: art. 6, ust. 1; Kubicki 2000: 19-26; Biesaga 2006: 9-13).

W każdym czasie donator może wycofać swój sprzeciw w formach, o których mowa powyżej. Chociaż model sprzeciwu, przyjęty w ustawodawstwie polskim dotyczącym transplantacji, wydaje się kłócić z interpretowaniem prawa do samostanowienia jako polegającego nie na domniemanym a wyraźnym, stanowczym wyrażeniu zgody, niewątpliwie jest najprostszym i najbardziej efektywnym sposobem pozyskiwania narządów do przeszczepienia od dawców zmarłych. Jednocześnie warto zwrócić uwagę, że w tak przyjętym rozwiązaniu wola rodziny zmarłego nie ma znaczenia, ponieważ zwłoki nie pozostają w dyspozycji prawnej, ani nie należą do masy spadkowej członków rodziny (Żaba et al. 2009: 164). Praktyka jednak nieznajdująca także uzasadnienia w Kodeksie Etyki Lekarskiej (Kodeks Etyki 2004: art. 33) wskazuje, że w przypadku braku sprzeciwu osoby zmarłej, lekarze z reguły pytają rodzinę o zgodę na pobranie narządów i szanują ich decyzję, nawet jeśli jest negatywna. Zgodnie z obowiązującymi przepisami nie muszą tego robić. W ten oto sposób sprzyjające pozyskiwaniu organów od zmarłych dawców prawo przestaje spełniać swoją funkcję i ulega praktyce życia (Ochmański 2011: 88).

1991 r., co pozwala domniemywać, że jego ustalenia miały wpływ na kształt ustawy transplantacyjnej z 1995 r. (Nowacka 1998: 47-57). 


\section{Dawstwo ex vivo}

W myśl art. 12 polskiej ustawy transplantacyjnej z 2005 r. pobranie komórek, tkanek lub narządów od osoby żywej może nastąpić w sytuacjach, gdy biorca wobec dawcy jest krewnym w linii prostej (rodzice, dzieci, wnuki, dziadkowie), rodzeństwem lub małżonkiem, osobą przysposobioną (adoptowaną), a także na rzecz innej osoby, jeżeli uzasadniają to szczególne względy osobiste. Donacja na rzecz osoby niespokrewnionej jest możliwa po spełnieniu warunków określonych w art. 13 omawianej ustawy, a więc wymaga zgody sądu rejonowego właściwego ze względu na miejsce zamieszkania lub pobytu dawcy, wydanego w postępowaniu nieprocesowym, po wysłuchaniu wnioskodawcy oraz po zapoznaniu się z opinią Komisji Etycznej Krajowej Rady Transplantacyjnej ${ }^{3}$.

Ustawodawca wyróżnił dwie grupy związków zachodzących pomiędzy żywymi dawcą a biorcą. Do pierwszej grupy należą osoby jasno wyszczególnione przez ustawodawcę. W świetle kodeksu rodzinnego i opiekuńczego nie nastręcza większych wątpliwości interpretacyjnych określenie, kiedy mamy do czynienia z małżeństwem, pokrewieństwem w linii prostej oraz rodzeństwem. Druga grupa podmiotów określona została przez ustawodawcę w sposób nieostry. Ustawodawca posłużył się klauzulą generalną "szczególnych względów osobistych", uzasadniając dopuszczalność pobrania komórek, tkanek czy narządów w celu przeszczepienia u niespokrewnionego biorcy (Haberko 2011: $45)$. W nauce prawa pod pojęciem klauzuli generalnej rozumie się zamieszczony w przepisie prawnym zwrot, który sam będąc kategorią prawa pozytywnego, odsyła do norm, kryteriów i wartości pozaprawnych, które mogą być uwzględnione przy stosowaniu

3 Postępowanie sądowe zostaje wszczęte na wniosek kandydata na dawcę z dołączoną do wniosku zgodą biorcy na przeszczep oraz orzeczeniem lekarza, pobierającego i przeszczepiającego je określonemu biorcy, dotyczącym celowości i zasadności takiej metody leczenia na podstawie aktualnego stanu wiedzy medycznej (Jankowski, Milecka 2009: 12-15). prawa w konkretnym przypadku (Radwański, Zieliński 2001: 11-16). Zastosowanie klauzuli "szczególnych względów osobistych" w ustawie transplantacyjnej upoważnia podmiot stosujący prawo (w tym przypadku lekarza lub sąd) do oparcia decyzji dotyczącej dopuszczalności pobrania i przeszczepu na wskazanych kryteriach pozaprawnych, które nie mogą być oceniane według sztywno zarysowanych w ustawie ram obejmujących kryteria podmiotowe dla dokonania omawianych zabiegów. Podmiot stosujący prawo ma zatem pewien luz decyzyjny w posługiwaniu się zwrotem nieostrym użytym przez ustawodawcę. Pozwala to w jednym przypadku uznać, że zachodzą szczególne względy osobiste, w innym zaś - że ich nie ma. Nie oznacza to, oczywiście, w żadnym wypadku dowolności. Uwzględnienie klauzuli „szczególnych względów osobistych” i dopuszczenie do transplantacji komórek, tkanek i narządów u niespokrewnionego dawcy wymaga uzasadnienia. Wypada także, by organ stosujący prawo z powołaniem się na klauzulę generalną jasno sformułował zasady, którymi kierował się przy rozstrzygnięciu w konkretnym przypadku (Haberko 2011: 46; Leszczyński, Maroń 2013: 88).

Zespół Prawny Krajowej Rady Transplantacyjnej wydał 14. września 2011 r. wytyczne dla Komisji Etycznej w zakresie interpretacji klauzuli „szczególnych względów osobistych”. Zespół ten podkreśla, że zastosowana konstrukcja służy uelastycznieniu tekstu ustawy i opowiada się za takim rozumieniem, aby „szczególne względy osobiste” traktowane były zgodnie $\mathrm{z}$ intencją ustawodawcy, czyli szeroko. Zdaniem Zespołu, powołanie się na klauzulę generalną „szczególnych względów osobistych" pozwala uwzględnić różnego rodzaju relacje pomiędzy dawcą i biorcą (np. szczególne relacje emocjonalne czy psychiczne), które nie mogą być postrzegane wedle jednego kryterium mającego walor bezwzględny ${ }^{4}$. Zespół uznaje dopuszczalność

4 Za taką interpretacją może przemawiać odwołanie się do wykładni historycznej. W poprzedniej ustawie transplantacyjnej z 1995 r. ustawodawca przyjmował dopuszczalność przeszczepów 
istnienia szczególnych względów osobistych w sytuacji: biologicznych krewnych w linii prostej (np. w sytuacji biologicznego ojca dziecka, które urodziło się w małżeństwie, albo którego ojcostwa nie ustalono); biologicznych krewnych w linii prostej osoby przysposobionej; małżonków po orzeczeniu rozwodu; przysposabiającego i przysposobionego po rozwiązaniu przysposobienia; krewnych w linii bocznej bez ograniczenia stopnia (np. kuzynostwo, ciocia, wujek, siostrzeniec, bratanek); przyrodniego rodzeństwa; powinowatych w linii prostej bez ograniczenia stopnia (np. teść, ojciec teścia, macocha, pasierb); powinowatych w linii bocznej bez ograniczenia stopnia (np. szwagier); przedstawicieli ustawowych niebędących krewnymi lub małżonkiem (np. opiekun); osób pozostających w bliskich stosunkach przyjacielskich (np. konkubentów czy homoseksualnych partnerów) czy zamieszkujących pod jednym dachem (np. studentów czy wychowańca, dzieci konkubenta z innego związku); osób pozostających w bliskich stosunkach towarzyskich czy zawodowych (np. narzeczeni, współpracownicy, znajomi). Zespół przyjmuje dopuszczalność wystąpienia szczególnych względów osobistych także w sytuacji tzw. przeszczepów krzyżowych z zachowaniem zasad wyznaczonych przez art. 12 i 13 ustawy. Stoi także na stanowisku, że powyższy katalog nie ma charakteru zamkniętego, a każdy przypadek powinien być poddany szczegółowej analizie Komisji Etycznej i sądu (Wytyczne Zespołu Prawnego Krajowej Rady Transplantacyjnej 2013: 107).

\section{Anonimowa donacja pomiędzy żyjącymi}

Dawstwo altruistyczne polega na tym, że dawca niespokrewniony z biorcą anonimowo i bezinteresownie oddaje swój narząd do przeszczepienia osobie obcej, nieznanej i nieokreślonej bezpośrednio przez siebie, nie

na rzecz osób bliskich (ustawa 1995: art. 9, ust. 1). Podobnie jak w obecnym stanie prawnym, pojęcie osoby bliskiej nie zostało zdefiniowane w sposób wyraźny. Porównanie obydwu redakcji skłania jednak do jednoznacznego wniosku, że intencją ustawodawcy było poszerzenie tej kategorii podmiotów. otrzymując za to żadnych korzyści. Pobrany od dawcy organ podlega procedurze bankowania w sposób analogiczny do organów pochodzących od dawców zmarłych. Z etycznego punktu widzenia postępowanie dawcy może być wysoko ocenione. Nie jest ono bowiem determinowane przez żadne czynniki zewnętrzne, np. takie jak przymus moralny, chęć zysku czy spełnienie zobowiązań, ani wewnętrzne w postaci egoistycznej motywacji czy zadośćuczynienia za wyrządzone komuś zło. Można mówić o pełnej dobrowolności działania i motywacji czysto altruistycznej. Z prawnego punktu widzenia, w myśl art. 12 ust. 1 pkt 2, ustawa zezwala na pobranie od anonimowych dawców wyłącznie szpiku i innych odnawialnych komórek lub tkanek. Takie ograniczenie przedmiotowe sprawia, że anonimowe dawstwo organów nieregenerujących się jest zakazane. Sankcji, w postaci grzywny lub kary ograniczenia lub pozbawienia wolności do lat 3, podlegałby tylko lekarz, zgodnie z treścią art. 46 ustawy. Dawca natomiast, który nie działa w celu uzyskania korzyści materialnej, nie popełnia czynu zabronionego opisanego w art. 44. Znowelizowane przepisy pozwalające na anonimowe oddanie narządu nieregenerującego się niespokrewnionej osoby hipotetycznie mogą prowadzić do zwiększenia puli dawców. Zadaniem ustawodawcy byłoby precyzyjne określenie przesłanek legalności zabiegu, w szczególności zaś kwestii dotyczących oświadczenia woli. W tym zakresie wzrosłaby także rola Komisji Etycznej Krajowej Rady Transplantacyjnej. Wydaje się jednak, że liczba anonimowych dawców organów nieregenerujących się może być znikoma, a tworzenie regulacji prawnych w tym zakresie bezprzedmiotowe (Ochmański 2011: 97-98).

\section{Ksenotransplantacje (przeszczepy odzwierzęce)}

Zgodnie z art. 20 Ustawy z dnia 1 lipca $2005 \mathrm{r}$. o pobieraniu, przechowywaniu i przeszczepianiu komórek, tkanek i narządów dopuszczalne jest przeszczepienie ludziom w celach leczniczych komórek, tkanek lub narządów pochodzących od zwierząt. Przeszczepienie 
takie wymaga uzyskania pozytywnej opinii Krajowej Rady Transplantacyjnej. Przy przeszczepie od zwierzęcia stosuje się ponadto przepisy dotyczące eksperymentów medycznych zawarte w ustawie o zawodach lekarza i lekarza dentysty (ustawa 1996: art. 21-29). Zgodnie z jej art. 29 ust. 1 eksperyment medyczny może być przeprowadzony wyłącznie po wyrażeniu pozytywnej opinii o projekcie eksperymentu przez niezależną komisję bioetyczną. Transplantacja ksenogeniczna znajduje zastosowanie wobec biorcy, kiedy stosowane wobec niego metody terapeutyczne nie były skuteczne lub ich skuteczność nie była wystarczająca. Kandydat na biorcę, jako uczestnik eksperymentu, musi być uprzednio poinformowany o celach, sposobach i warunkach przeprowadzenia eksperymentu, spodziewanych korzyściach leczniczych, ryzyku oraz możliwości odstąpienia od udziału w eksperymencie w każdym jego stadium.

Ksenotransplantacje, oprócz odpowiedzi na najbardziej zasadniczy problem, jakim jest niedostatek narządów i tkanek, posiadają wiele innych zalet. Po pierwsze, mogą stanowić dopuszczalną alternatywę w krajach, w których przeszczepy allogeniczne są zabronione ze względów religijnych. Po drugie, parametry konkretnego produktu ksenotransplantacyjnego mogą być dokładnie zbadane i opisane, a sam przeszczep precyzyjnie zaplanowany pod względem wyboru optymalnego terminu. Ponadto, w przypadku ksenotransplantacji wyeliminowane zostają negatywne konsekwencje charakterystyczne dla transplantacji organów pozyskanych od zmarłych dawców (np. patofizjologiczny wpływ śmierci mózgu na organy). Po trzecie, kryteria doboru biorców mogą być poszerzone ze względu na szeroki i udokumentowany dostęp do organów. Po czwarte, pozyskiwanie produktów ksenotransplantacyjnych w warunkach pełnej kontroli i poddawanie ich modyfikacjom genetycznym może zwiększyć skuteczność przeszczepów z punktu widzenia immunologicznego (Smorąg, Słomski 2005: 140-141).
Wielokrotnie podejmowane kliniczne próby przeszczepiania narządów od zwierząt kończyły się jednak niepowodzeniem, co rodzi uzasadnioną nieufność wobec tego typu praktyk. Postawa ta znajduje uzasadnienie w następujących argumentach: zarówno operacje, jak i opieka pooperacyjna generują ogromne koszty przy znikomych efektach; pojawia się ryzyko śmierci, większe od tego, które zaistniałoby w sytuacji, gdyby lekarze powstrzymaliby się od tego rodzaju zabiegów; przeszczepianie narządów zwierzęcych powoduje opór psychiczny pacjentów utrudniający skuteczność takiej terapii (Raniszewska-Wyrwa 2010: 279); pojawia się również zagrożenie związane z ewentualnym przeniesieniem na człowieka wirusowych chorób zwierząt (Fikus 1999: 101).

Idea ksenotransplantacji wywołuje także zrozumiałe pytania natury etycznej, prawnej, religijnej i światopoglądowej. Stanowią one przedmiot dyskusji, która powinna mieć wpływ na kierunki rozwoju uregulowań prawnych odnoszących się pośrednio lub bezpośrednio do przeszczepów heterogenicznych. Lista argumentów ulega ciągłym zmianom i pozostaje nadal otwarta (Raniszewska-Wyrwa 2010: 141). Większość zastrzeżeń dotyczy stosowania w medycynie rozwiązań eksperymentalnych, a takimi wciąż są, mimo znacznego rozwoju transplantologii, przeszczepy organów odzwierzęcych. W kontekście prowadzenia dalszych testów klinicznych pojawia się szereg zasadniczych pytań: czy spełniony jest warunek, iż spodziewane korzyści w zdecydowany sposób przewyższają potencjalne ryzyko; czy istnieją możliwe do zastosowania metody alternatywne pozwalające pomóc pacjentowi, który rozważany jest jako kandydat do testów klinicznych; czy wybór pacjenta przeznaczonego do uczestnictwa w próbie klinicznej jest odpowiednio uzasadniony. Odpowiedź na te pytania będzie miała znaczący wpływ na kierunek i dalszy rozwój ksenotransplantacji (Smorąg, Słomski 2005: 141). Ksenotransplantacje wiążą się także z żywą dyskusją na temat moralnej dopuszczalności zabijania zwierząt (Singer 
1998: 181; Schweitzer 1974: 51), a także poddawania ich specjalnym modyfikacjom genetycznym („uczłowieczenie” zwierząt poprzez wprowadzenie genów ludzkich) w celu przeciwdziałania nadostremu odrzuceniu (Cierpka, Caban 2015: 347-350; Raniszewska-Wyrwa 2010: 284-285). Wziąwszy pod uwagę zasygnalizowane trudności, należy podkreślić większą ilość wątpliwości i wad niż zalet wynikających ze stosowania ksenotransplantacji.

\section{Zakończenie}

W moim przekonaniu polskie regulacje prawne w zakresie transplantologii w optymalny sposób sprzyjają pozyskiwaniu organów. Po pierwsze, pobieranie organów od dawców zmarłych regulowane jest zgodnie z modelem tzw. zgody domniemanej. Po drugie, ustawodawca, posługując się nieostrą klauzulą generalną „szczególnych względów osobistych", dopuszcza możliwość pobrania komórek, tkanek czy narządów w celu przeszczepienia u żywego dawcy niespokrewnionego z biorcą. Po trzecie, ustawa zezwala na pobranie od anonimowych dawców szpiku i innych regenerujących się komórek i tkanek. Po czwarte, w myśl polskiej ustawy transplantacyjnej dopuszczalne jest przeszczepienie ludziom w celach leczniczych komórek, tkanek lub narządów pochodzących od zwierząt.

Powstaje jednak zasadne pytanie: co jeszcze można zrobić, by zmniejszyć dysproporcję pomiędzy zapotrzebowaniem, a dostępnością narządów. W świetle wiedzy medycznej niewątpliwe jest to, że narządy pozyskiwane od żywych dawców rokują większe nadzieje na udany przeszczep. Stąd też, uważam, że, poprawiając lub tworząc nowe regulacje, więcej uwagi należy poświęcić temu kręgu dawców i unormowaniom dotyczącym wykorzystywania komórek macierzystych w celach terapeutycznych. Odpowiadając na problem niedostatku narządów i tkanek, należałoby także przeznaczyć większe środki na rozwój bardziej perspektywicznych metod transplantologii, chociażby alloplastykę, która nie niesie ze sobą tak poważnych zagrożeń jak ksenotransplantacje. Należy jednak podkreślić, że głównymi przyczynami spadającej liczby transplantacji jest niski poziom świadomości społecznej, brak dostatecznej wiedzy na temat dawstwa narządów i atrofia postaw współczujących. Aby zmniejszyć dysproporcję pomiędzy zapotrzebowaniem a dostępnością narządów, należy więc zintensyfikować działania na rzecz propagowania idei ofiarności organów i opracowania właściwej strategii edukacyjnej na temat transplantacji. Bez tych długofalowych działań, wymagających czasu i zaangażowania wielu środowisk, przyszłość medycyny przeszczepowej trudno będzie nazwać satysfakcjonującą.

\section{Bibliografia}

Biesaga T., 2006, Wobec zgody domniemanej i zawtaszczania zwłok do transplantacji, Medycyna Praktyczna Ginekologia i Położnictwo, vol. 2, 9-13.

Cierpka L., Caban A., 2015, Biotechnologiczne i medyczne podstawy ksenotransplantacji, w: Durlik M., Cierpka L. (red.), Transplantologia kliniczna. Zasady ogólne, Termedia Wydawnictwa Medyczne, Poznań, 345-355.

Durlik M., Cierpka L., 2015, Przedmowa, w: Durlik M., Cierpka L. (red.), Transplantologia kliniczna. Zasady ogólne, Termedia Wydawnictwa Medyczne, Poznań, 15.

Fikus M., 1999, Zwierzęta transgeniczne, w: Chyrowicz B. (red.), Klonowanie człowieka. Fantazje zagrożenia - nadużycia, TN KUL, Lublin, 93-106.

Haberko J., 2011, „Szczególne względy osobiste” a przeszczep od żywego dawcy, Państwo i Prawo, vol. 7-8, 44-53.

Jankowski Z., Milecka A., Raszeja S., 2009, Prawne podstawy przeszczepiania narzadów, w: Rutkowski B., Kaliciński P., Śledziński Z., Wujtewicz M., Milecka A., Wytyczne dotyczace zasad zgtaszania, kwalifikacji i przygotowania zmartych dawców do pobrania narządów, Via Medica, Gdańsk, 12-23.

Kodeks Etyki Lekarskiej, tekst jednolity z 2 stycznia 2004 r., zawierający zmiany uchwalone w dniu 20 września 2003 r. przez Nadzwyczajny VII Krajowy Zjazd Lekarzy.

Kubicki L., 200o, Prawo medyczne - próba ustalenia zakresu, Prawo i Medycyna, vol. 5, 19-26. 
Leszczyński L., Maroń G., 2013, Pojęcie i treść zasad prawa i generalnych klauzul odsyłajacych. Uwagi porównawcze, Annales UMCS. Sectio G., vol. 6o, nr 1, 81-91.

Nowacka M., 1998, Etyczno-prawne kwestie otwarte w polskim Kodeksie Etyki Lekarskiej, Idea: Studia nad strukturą i rozwojem pojęć filozoficznych, vol. 10, 147-157.

Ochmański J., 2011, Regulacje prawne a wyzwania wspótczesnej medycyny transplantacyjnej. Problematyka poszerzenia kręgu dawców organów nieregenerujacych się, w: Such J., Wiśniewski J. (red.), Z filozoficznych, etycznych i prawnych zagadnień transplantacji, Wydawnictwo Naukowe UAM, Poznań, 81-10o.

Radwański Z., Zieliński M., 2001, Uwagi de lege ferenda o klauzulach generalnych $w$ prawie prywatnym, Przegląd Legislacyjny, vol. 2, 11-16.

Raniszewska-Wyrwa A., 2010, Transplantologia eksperymentalna. Ksenotransplantacje - nadzieja czy zagrożenie, Humanistyka i Przyrodoznawstwo, vol. 16, 277-289.

Schweitzer A., 1974, Życie, PAX, Warszawa.

Singer P., 1998, O życiu i śmierci. Upadek etyki tradycyjnej, PIW, Warszawa.

Smorąg Z., Słomski R., 2005, Ksenotransplantacjamożliwości i ograniczenia, Nauka, vol. 4, 133-148.
Tokarczyk R., 200o, Zarys regulacji transplantacji organów ludzkich, Ruch Prawniczy, Ekonomiczny i Socjologiczny, vol. 62, z. 1, 15-31.

Ustawa $\mathrm{z}$ dnia 1 lipca 2005 r. o pobieraniu, przechowywaniu i przeszczepianiu komórek, tkanek i narządów (Dz.U.2005.169.1411).

Ustawa z dnia 26 października 1995 r. o pobieraniu i przeszczepianiu komórek, tkanek i narządów (Dz.U.1995.138.682).

Ustawa z dnia 5 grudnia 1996 r. o zawodach lekarza i lekarza dentysty (Dz.U.2005.226.1943).

Wytyczne Zespotu Prawnego Krajowej Rady Transplantacyjnej dla Komisji Etycznej w zakresie interpretacji klauzuli „szczególnych względów osobistych" przy pobraniu narzadów od żywych dawców niespokrewnionych, 2013, Poltransplant. Biuletyn Informacyjny, 21, 107.

Żaba C., Świderski P., Żaba Z., Grześkowiak M., 2009, Prawno-medyczne aspekty pobierania narzadów ze zwtok, Nowiny Lekarskie, vol. 78, z. 2, 159-164. Żelichowski M., 2009, Aspekty prawne transplantacji, Medycyna Praktyczna, vol. 1, 145-147.

(Web-01) Poltransplant. Statystyka 2017, http://www. poltransplant.org.pl/statystyka_2017.html, dostęp: 25.06.2018.

\section{Organ donation in polish transplantation regulations}

\section{Abstract}

The key problem for the modern transplantation practice is the decrease of the number of donors in view of constantly rising demand for tissues and organs. This article is an attempt to respond to the question about whether and to what extent Transplant Act on Cells, Tissues and Organ Retrieval and Transplantation of $1^{\text {st }}$ July 2005 counteracts the decrease of the number of transplants. The author takes the view that Polish transplantation regulations create a favourable environment for organ donation. First of all, article 5 states that transplantation of organs for a therapeutic reason is possible when the deceased person distinctly hadn't disagreed for such an action. If there are no clear objections against transplantation, and the deceased person does not carry a note of which could suggest otherwise, the physician can legally assume that the person had agreed for an organ sampling (from a presumed consent). Second, Polish law allows organ donation from a living unrelated donors if particular personal reasons justify it. Three, Polish transplantation regulations accept also donation from anonymous donors of bone marrow and other regenerating cells or tissues. Finally, the law admits transplantation of cells, tissues and organs coming from animals to people for healing purposes. That does not actually mean that the existing law is ideal. It must be stressed, however, that the main reason of the decrease of the number of transplants in Poland is the disastrously insufficient state of social consciousness caused by the insufficient public education and lack of educational strategy.

\section{Keywords}

transplantology, donation, deceased donor, living donor, donation anonymous, xenotransplantation 